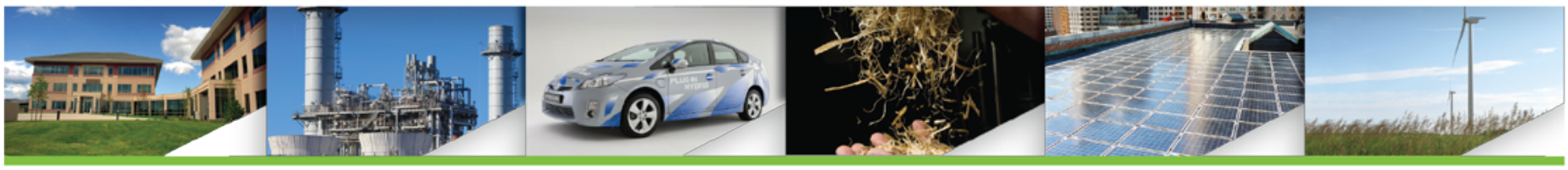

\title{
Exploring the Potential Business Case for Synergies Between Natural Gas and Renewable Energy
}

Jaquelin Cochran, Owen Zinaman, Jeffrey Logan, and Doug Arent National Renewable Energy Laboratory (NREL)

The Joint Institute for Strategic Energy Analysis is operated by the Alliance for Sustainable Energy, LLC, on behalf of the U.S. Department of Energy's National Renewable Energy Laboratory, the University of Colorado-Boulder, the Colorado School of Mines, the Colorado State University, the Massachusetts Institute of Technology, and Stanford University.

Technical Report

NREL/TP-6A50-60052

February 2014

Contract No. DE-AC36-08GO28308 


\section{Exploring the Potential Business Case for Synergies Between Natural Gas and Renewable Energy}

Jaquelin Cochran, Owen Zinaman, Jeffrey Logan, and Doug Arent

National Renewable Energy Laboratory (NREL)

Prepared under Task No. WWJI.1015

The Joint Institute for Strategic Energy Analysis is operated by the Alliance for Sustainable Energy, LLC, on behalf of the U.S. Department of Energy's National Renewable Energy Laboratory, the University of Colorado-Boulder, the Colorado School of Mines, the Colorado State University, the Massachusetts Institute of Technology, and Stanford University.

JISEA $^{\circledR}$ and all JISEA-based marks are trademarks or registered trademarks of the Alliance for Sustainable Energy, LLC.

The Joint Institute for Strategic Energy Analysis 15013 Denver West Parkway Golden, CO 80401 303-275-3000 • www.jisea.org
Technical Report

NREL/TP-6A50-60052

February 2014

Contract No. DE-AC36-08GO28308 


\section{NOTICE}

This report was prepared as an account of work sponsored by an agency of the United States government. Neither the United States government nor any agency thereof, nor any of their employees, makes any warranty, express or implied, or assumes any legal liability or responsibility for the accuracy, completeness, or usefulness of any information, apparatus, product, or process disclosed, or represents that its use would not infringe privately owned rights. Reference herein to any specific commercial product, process, or service by trade name, trademark, manufacturer, or otherwise does not necessarily constitute or imply its endorsement, recommendation, or favoring by the United States government or any agency thereof. The views and opinions of authors expressed herein do not necessarily state or reflect those of the United States government or any agency thereof.

Available electronically at http://www.osti.gov/bridge

Available for a processing fee to U.S. Department of Energy and its contractors, in paper, from:

U.S. Department of Energy

Office of Scientific and Technical Information

P.O. Box 62

Oak Ridge, TN 37831-0062

phone: 865.576 .8401

fax: 865.576 .5728

email: mailto:reports@adonis.osti.gov

Available for sale to the public, in paper, from:

U.S. Department of Commerce

National Technical Information Service

5285 Port Royal Road

Springfield, VA 22161

phone: 800.553 .6847

fax: 703.605.6900

email: orders@ntis.fedworld.gov

online ordering: http://www.ntis.gov/help/ordermethods.aspx

Cover Photos: (left to right) PIX 04135, iStock 22779761, PIX 16933., PIX 15648, PIX 08466, PIX 21205

Printed on paper containing at least $50 \%$ wastepaper, including $10 \%$ post consumer waste. 


\section{Acknowledgments}

This paper was prepared with input and feedback from many experts. The authors would like to acknowledge Mark Boling, Southwestern Energy; Steven Corneli, NRG Energy; Sherman Knight, Competitive Power Ventures; Morgan Bazilian, Joint Institute for Strategic Energy Analysis (JISEA); and Dean Armstrong, Scott Gossett, Mike Meshek, Mary Lukkonen, Niccolo Aieta, and Ben Sigrin, National Renewable Energy Laboratory. The authors would also like to acknowledge the numerous and substantial contributions made by participants at the September 2013 Leadership Forum on this topic hosted by JISEA and the Center for the New Energy Economy. 


\section{Abstract}

Natural gas and renewable energy each contribute to economic growth, energy independence, and carbon mitigation, sometimes independently and sometimes collectively. Often, natural gas and renewables are considered competitors in markets, such as those for bulk electricity. This paper attempts to address the question, "Given near- and long-term needs for abundant, cleaner energy sources and decarbonization, how can more compelling business models be created so that these two domestic forms of energy work in greater concert?" This paper explores revenue opportunities that emerge from systems-level perspectives in "bulk energy" (large-scale electricity and natural gas production, transmission, and trade) and four "distribution edge" subsectors: industrial, residential, commercial, and transportation end uses.

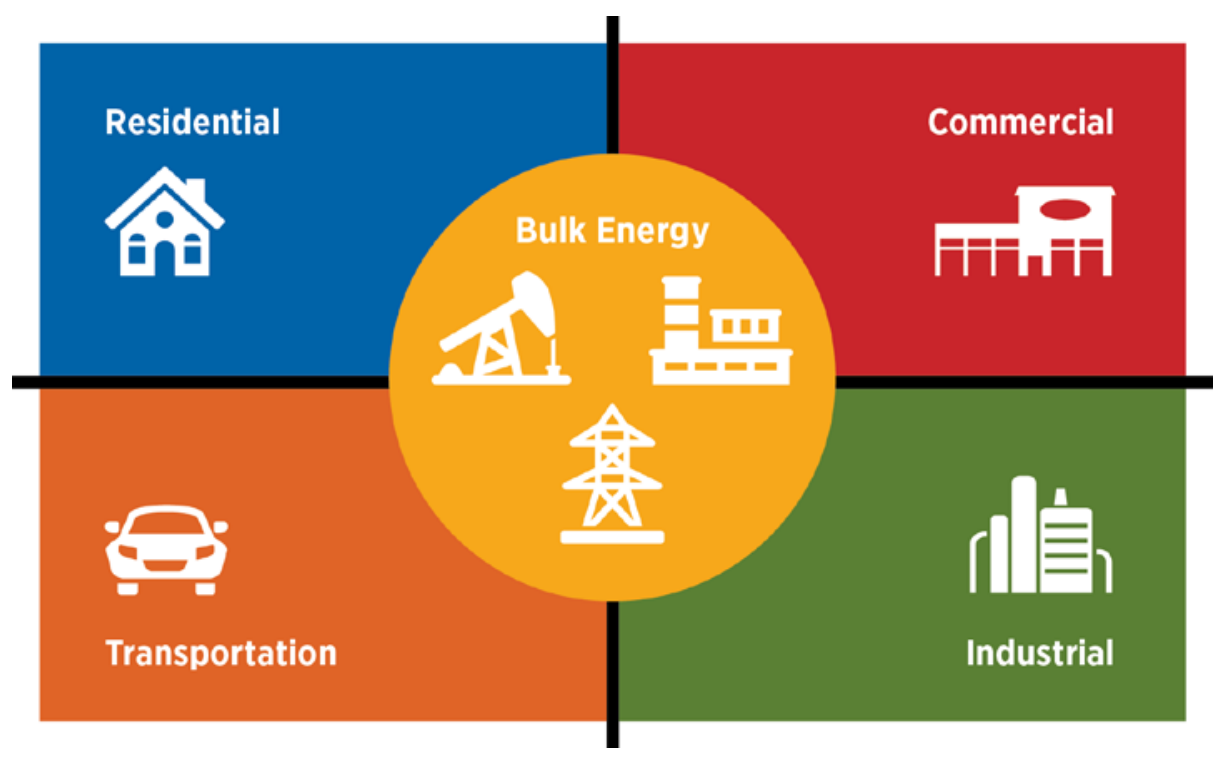

Synergies between natural gas and renewable energy are found to exist at multiple levels: from hybrid systems that optimize assets - e.g., smart buildings with both photovoltaic (PV) and natural gas combined heat and power (CHP) systems - to transmission corridors that serve both technologies. The business models that capitalize on both renewable energy and natural gas can access new revenue streams, including wholesale market opportunities for the distribution edge (e.g., demand response aggregation), upstream and downstream arbitrage opportunities from shared infrastructure, and energy services that offer the customer resiliency, reliability, and reduced costs. 


\section{Table of Contents}

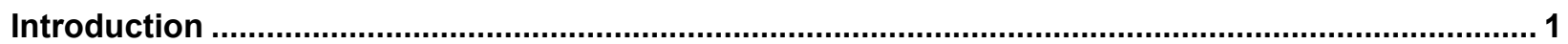

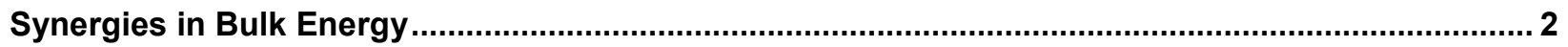

Synergies at the "Distribution Edge"

Industrial Cogeneration— Optimization for Multiple Markets................................................... 8

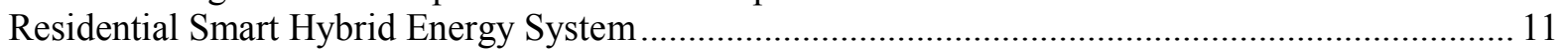

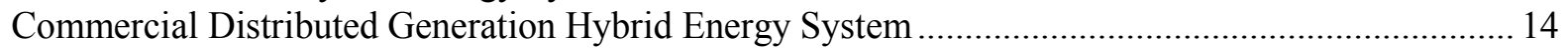

Transportation-Arbitrage Opportunities through Alternative Fuel Vehicles................................... 17

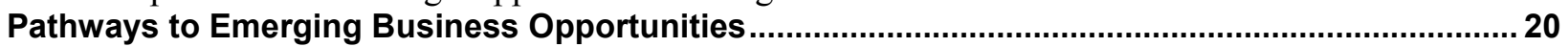

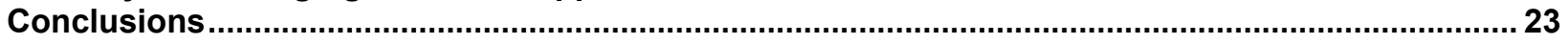

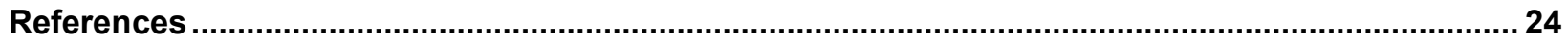

Appendix. Recent JISEA Publications on Natural Gas and Renewable Energy .............................. 27

\section{List of Figures}

Figure 1. Examples of revenue opportunities from synergies in the bulk energy sector ...............6

Figure 2. Examples of revenue opportunities from synergies in the industrial sector....................9

Figure 3. Examples of revenue opportunities from synergies in the residential sector ................12

Figure 4. Examples of revenue opportunities from synergies in the commercial sector ..............15

Figure 5. Examples of revenue opportunities from synergies in the transportation sector............18

\section{List of Text Boxes}

Text Box 1. Value Proposition of Synergies in the Bulk Power Sector ...................................... 7

Text Box 2. Untapped Technical Potential .......................................................................

Text Box 3. Value Proposition of Synergies in the Industrial Sector........................................10

Text Box 4. Value Proposition of Synergies in the Residential Sector .....................................13

Text Box 5. Value Proposition of Synergies in the Commercial Sector .....................................16

Text Box 6. Value Proposition of Synergies in the Transportation Sector.................................19 


\section{Introduction}

In his 2013 State of the Union address, ${ }^{1}$ President Obama heralded the contributions of both natural gas and renewable energy in creating economic growth, strengthening energy independence, and reducing the threat of climate change. The United States is in the midst of an energy transition with a relative abundance of unconventional natural gas and oil. Deployment of renewable energy and energy efficiency is also growing at record levels. These developments have begun to transform the national energy landscape, and spurred reevaluation of the most effective way to provide consumers with reliable and low-cost energy services in the context of broader public policy objectives.

Often, natural gas and renewables are considered competitors in markets, such as those for bulk electricity. This paper, building on previous work by the Joint Institute for Strategic Energy Analysis (JISEA), attempts to address the question, "Given near- and long-term needs for abundant, cleaner energy sources and decarbonization, how can more compelling business models be created so that these two domestic forms of energy work in greater concert?"

This paper explores some potential revenue opportunities in which natural gas and renewables may offer a better value proposition by working together. Synergies between natural gas and renewable energy are found to exist at multiple levels: from hybrid systems that optimize assets - e.g., smart buildings with both PV and natural gas CHP systems - to investment portfolios that address business and financial risks through asset diversification.

Evaluating these potential synergies raises many questions, at all scales, including:

- What technical, spatial, temporal, and financial synergies might exist in bulk and distributed energy systems?

- Might wind and natural gas developers consider new business models such as joint transmission investments?

- What are the pros and cons of considering hybrid gas-renewable system configurations and services?

Potential business configurations for synergies between natural gas and renewable energy are explored in five sectors: bulk energy, ${ }^{2}$ and - at the distribution edge of the electricity and natural gas networks - industrial, residential, commercial, and transportation end uses. Throughout the paper, illustrations and examples are meant to spur thought, discussion, and action. They do not represent a comprehensive list of opportunities or of any complete value chain. ${ }^{3}$

\footnotetext{
${ }^{1}$ For the full text of the address, see http://www.whitehouse.gov/photos-and-video/video/2013/02/12/2013-stateunion-address-0.

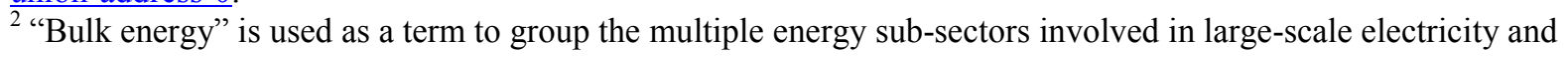
natural gas production, transmission, and trading.

${ }^{3}$ While this paper explores opportunities at the distribution edge by sector, many opportunities for collaboration exist across sectors.
} 


\section{Synergies in Bulk Energy}

The U.S. electric sector is experiencing unprecedented change due to a combination of lowpriced natural gas, stricter environmental standards, and rapid growth of wind and solar generation. These changes have led to a swift decline in coal and oil fired generation.

Low-priced natural gas has not only impacted coal use, but it has also been presented as "crowding out" nuclear and renewables (Lacey 2012; Weiss et al. 2013). However, rather than view these industries as competitors, we can note that natural gas and renewable energy investments have different risk profiles and offer complementary portfolio benefits (Lee et al. 2012). ${ }^{4}$ Typically, these complementarities relate to financial risk hedging and reliability (Wiser et al. 2004; Jenkin et al. 2013). For example, wind and solar energy have no fuel costs and therefore zero fuel price risk across all timeframes, but their variable and uncertain generation profiles require a flexible, responsive power system. Power generation based on natural gas offers the flexibility and increased dispatchability that complements renewable energy power generation but at the risk of increased fuel price volatility and the challenge, in some regions, of ensuring adequate and timely gas deliverability (O'Loughlin et al. 2012). Furthermore, while natural gas has clear environmental advantages when used in place of coal, it still emits greenhouse gases; the long-term risks to a portfolio of generating options might be managed by adding renewables (Logan et al. 2012).

Planning tools that incorporate portfolio risk are one option that may lead to more complementary natural gas and renewable energy use (Synapse 2006; Gampert and Madlener 2010; Swisher 2011). This option, however, does not fully capture potential business opportunities for both energy sources in bulk energy markets. Additional synergistic opportunities include joint transmission corridors, colocation, hybrid energy systems, wholesale power markets, increased coordination, and joint financing.

\section{Joint Transmission Corridors}

Transmission infrastructure, including electricity lines and natural gas pipelines, is key to opening market opportunities for renewable energy and natural gas in rural areas. Particularly for areas in the Midwest, such as North Dakota, wind and natural gas resources are abundant; yet, with insufficient transmission capacity to gather and deliver energy, development is limited or potential profits literally flared. Stakeholders could propose joint transmission corridors (for pipelines, roads, and wires) to service resource-rich areas. These investment opportunities could have powerful benefits in reducing flared natural gas and boosting access to very high quality wind resources, for example.

\footnotetext{
${ }^{4}$ Nuclear, coal, and other power generation technologies also have distinctly different risk profiles than natural gas, but they are beyond the scope of this paper.
} 


\section{Colocation}

Many technologies can offer benefits from joint location. These include:

- Natural gas, wind, and compressed air energy storage (CAES)

- Excess wind-to-synthetic gas, sold into existing pipeline infrastructure

- Depleted natural gas wells converting to geothermal or CAES

- Wastewater treatment facilities that use waste heat from natural gas power plants to create clean energy products, such as biogas or high-purity hydrogen for fuel cells.

Colocated plant generation can boost capacity factors and returns on investment in transmission lines. Natural gas and wind developers may independently have existing partnerships with mineral owners, surface owners, industry, and utilities; partnering on locations to establish generation could expand the availability of sites to both industries.

\section{Hybrid Energy Systems}

Hybrid energy systems are being developed to increase plant efficiency and flexibility, manage renewable variability, and decrease fuel price risk. For example, GE's 530-megawatt generation plant under construction in Karaman, Turkey, will integrate gas, solar thermal, and wind within the plant's design, increasing its efficiency and improving operator control (Olson 2011). Solar Energy Generating Systems' concentrating solar power (CSP) facilities in California combust natural gas when solar output drops, allowing the operator to guarantee delivery of electricity in support of power purchase agreements. Hybrid systems can also take the form of natural gas combined cycle plants using supplemental CSP steam.

\section{Wholesale Power Markets}

New market products and associated structures might be created to combine variable renewable energy and flexible gas generation into a single firm, low-emissions product (McAndrews and Lawrence 2012). This is occurring to a limited extent in the Bonneville Power Administration (BPA) balancing area, where Iberdrola Renewables holds contracts with natural gas generators in order to supply firm power to utilities, thus bypassing BPA's less flexible hourly dispatch and mitigating forecast errors, energy imbalances, and integration charges (Hardy 2009).

Alternatively, new market products may be created to ensure the availability of flexible natural gas-fired generation to support a high level of renewable penetration (Cochran et al. 2013). For example, California Independent System Operator has proposed a flexible capacity product for generators with fast ramp capabilities to ensure the system has resources capable of meeting increasingly large and rapid net load fluctuations. ${ }^{5}$ A dispersed portfolio of diverse generating assets including gas and renewables might be managed using an integrated operations optimization strategy and be bid into wholesale spot markets to maximize revenue and manage risk.

\footnotetext{
${ }^{5}$ For additional background on this product, see http://www.caiso.com/Documents/SecondRevisedDraftFinalProposal-FlexibleRampingProduct.pdf.
} 


\section{Increased Coordination}

Some planners and regulators hold misperceptions about the challenges and capabilities of variable renewable electricity generation. And, some regulators still require that proposals for variable renewable plants include locally sited natural gas facilities to manage renewable variability, even though studies have shown that this variability can be minimized more cost effectively through other means, such as broad geographic dispatch of generation sites (EnerNex Corporation 2010; GE Energy 2010; Cochran et al. 2012; Porter et al. 2012). Also, if incentivized, variable renewable electricity can provide many grid services (e.g., inertial response, see Ela et al. 2012). Coordination and stakeholder communications of that capability offer a means to avoid stranded capital and maximize returns on limited investments. This in turn may result in gas plants more optimally located on the electric/gas transmission system to mitigate the risk of congestion; furthermore, with fewer geographic constraints on potential constructions sites, gas project developers might be able to leverage existing relationships, take advantage of local or state economic development incentives, or use other industry wisdom to develop plants at more favorable locations. Separately, the two industries would also benefit from better coordination of day-ahead dispatch scheduling of power markets and gas procurement scheduling in gas markets (Lee et al. 2012). Scheduling in natural gas and electricity markets occurs independently and in disharmony. Generators in NYISO, ISO New England, and PJM Interconnection, for example, must purchase gas for their next day of operation before receiving operating schedules from the grid for that day (Tabors et al. 2012). If generators require more or less gas than their initial estimate, they may have to buy or sell gas in the illiquid intraday gas market, or face imbalance penalties.

\section{Joint Financing}

Investments in renewable energy generation have, until recently, been project-specific, illiquid, and primarily limited to investors who can utilize the tax credit benefits (Mendelsohn et al. 2012). Natural gas project financing spans broad mechanisms across the supply chain, from production-sharing-for-equity arrangements, to collateralized debt obligations or master limited partnerships ${ }^{6}$ (MLPs) for midstream infrastructure projects, to asset and debt securitization, ${ }^{7}$ to synergistic joint ventures between equity or institutional investors and experienced power plant operators. For renewables, new financing models, such as securitization, expand the types of capital available to finance renewable energy (e.g., from pension funds, individual investors, crowdsourcing) (Mendelsohn and Feldman 2013).

These financing models offer several opportunities that build on synergies between natural gas and renewable energy. For example, colocated assets could be financed or securitized together-

\footnotetext{
${ }^{6}$ MLPs allow investors to publicly trade shares of a partnership, which is not subject to the corporate income tax. The single layer of taxation and the publicly traded shares lower the cost of capital and increases liquidity. Federal law restricts MLPs to select industries, such as oil and gas pipelines; legislation currently under consideration by Congress would be needed to expand MLP treatment to renewable energy. For additional background on the legislation, see http://www.coons.senate.gov/issues/master-limited-partnerships-parity-act.

${ }^{7}$ Securitization pools financial obligations that can then be divided and sold as securities to investors. For example, the leases and power purchase agreement payments from solar projects can be pooled from across projects and used to back securities, and proceeds from the sale of those securities could be reinvested in new systems (Schwabe et al. 2012).
} 
this could include wind colocated with combined cycle gas turbines, with a utility as the "offtaker" or on-site distributed generation of PV and fuel cells, with large commercial entities as the offtaker. In addition, independent investments in renewable energy and natural gas can be pooled and securitized, reducing systematic portfolio risks (e.g., from changes to fuel prices or regulations). Large asset owners could spin off public companies that specialize in renewable energy and natural gas under a YieldCo structure. ${ }^{8}$ For example, NRG Energy Inc. recently completed an initial public offering for its YieldCo. The YieldCo owns a mix of renewable energy and natural gas generation assets, listed on the New York Stock Exchange, which will pay regular dividends to shareholders.

\section{Examples of Revenue Flows from Bulk Energy Synergies}

Figure 1 illustrates the potential flows of revenue from synergies in the bulk energy sector for three separate scenarios:

1. An independent power producer (IPP) creates a shell corporation called a special purpose vehicle to develop, build, and own colocated plants-(e.g., wind colocated with a combined cycle gas turbine); the utility is the offtaker. The special purpose vehicle then receives debt financing from an investment bank and sells a portion of its equity in the special purpose vehicle to pension funds, infrastructure funds, and others. A power marketer, not illustrated in the figure, purchases power from the IPP in a day-ahead market and sells it to the utility offtaker via a pre-existing power purchase agreement. The colocation of assets offers cost savings opportunities for dual utilization of on-site infrastructure (e.g., roads and substations), optimized transmission utilization, behindthe-bus management of renewable variability, and perhaps tax benefits.

2. A publicly-traded subsidiary of an energy generator finances and owns a diverse collection of assets, including renewable energy generation and natural gas generation, to create a low-risk investment portfolio. Multiple utilities are the offtakers. The publicly traded company strategically colocates with a drilling rig site owned by an oil and gas development company (not pictured) to build a transmission corridor. The company is traded via shares on the stock exchange, open to any investor class; dividends are paid out of long-term contracts with the utilities.

3. A load serving entity owns a hybrid gas-solar-wind energy system. The diverse source of fuels reduces risk and the firm capacity expands wholesale power market opportunities for the utility.

\footnotetext{
${ }^{8} \mathrm{~A}$ YieldCo is a public company whose assets consist primarily of renewable and natural-gas fired generating assets with regular income streams, such as power purchase agreements. The majority of cash flows from these assets are distributed to investors. Unlike MLPs, YieldCos themselves do not create a tax advantage. However, coupling renewable assets that receive tax credits with natural gas assets that create taxable income under such a structure ensures that the value of the PTC is preserved and not lost to tax equity investors.
} 


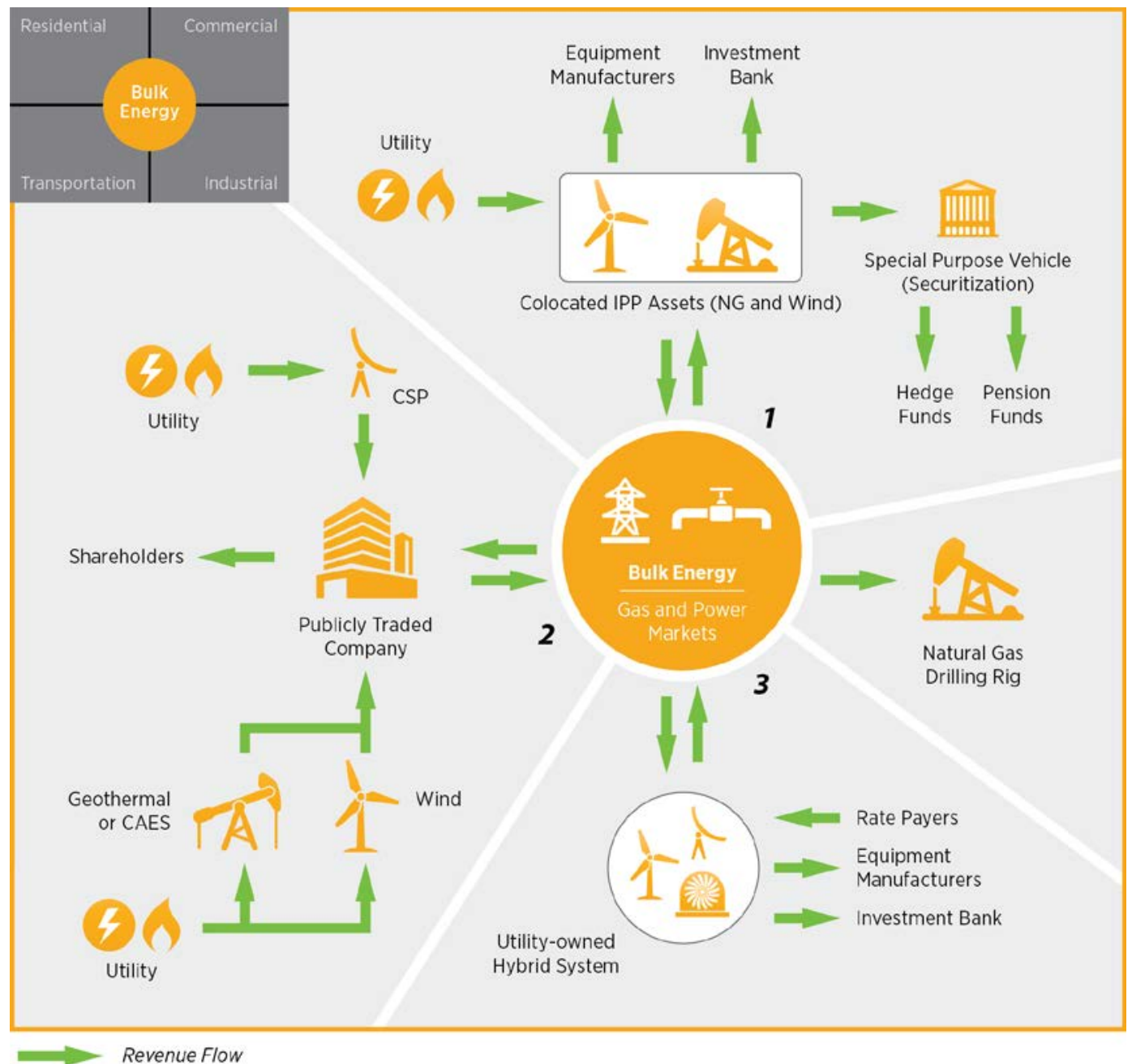

Figure 1. Examples of revenue opportunities from synergies in the bulk energy sector.

1) Strategically colocated, securitized wind and natural gas (NG) generation assets owned by an IPP. 2) Publicly traded energy company utilizing a diverse portfolio of assets, joint transmission corridors, and novel storage opportunities. 3) Hybrid energy system owned by a utility. Green arrows represent revenue flows.

\section{Opportunities for Revenue in Synergistic Bulk Energy Development}

Colocation of plant facilities and transmission corridors, new financing mechanisms, and coordinated development of renewable and natural gas projects offer significant opportunities for cost savings and additional revenue streams. Project developers might avoid such opportunities because of added complexity and uncertainty; Text Box 1 intends to address these barriers by describing the emerging value propositions of these opportunities - for the customer (in this example, the utility offtaker) and for the renewable energy and natural gas supply chains. 
Text Box 1. Value Proposition of Synergies in the Bulk Power Sector

Colocation, coordination, and wholesale markets offer many opportunities for cost saving synergies and additional revenues in the bulk energy sector, including 1) planning and development of transmission corridors, 2) improved utilization of transmission lines, 3) reduced portfolio risks, and 4 ) increased market opportunities (e.g., through hybrid systems or colocated renewable energy and natural gas). In addition, new financing models can expand access to low-cost capital for both natural gas and renewable energy developers, and can provide investors a diverse, lower-risk portfolio than single-project investments do.

\section{Value proposition of synergy for:}

Customer (utility offtaker)

Improved planning; improved operator control (for hybrid system); lower transmission expenses

Energy portfolio with reduced systemic risks

Renewable energy supply chain

More efficient planning of transmission

Improved wholesale power market opportunities from firm capacity

Expanded access to financing and associated increased production

Temperature and other data from natural gas exploration to improve resource assessments for geothermal production

\section{Natural gas supply chain}

More efficient planning of transmission

For hybrid systems, lower net emissions (e.g., carbon dioxide, nitrogen oxides) and lower marginal costs

Increased financing and associated increased production 


\section{Synergies at the "Distribution Edge"}

A different set of potential business drivers could leverage gas and renewable use at the distribution edge. These drivers include industry, commercial sites, homes, and vehicles. Multiple technology solutions that build from the potential synergies, such as "islandable" energy systems, on-site CHP, alternative transportation fuels, and hydrogen production for fuel cells and other uses, could meet the evolving, complex energy needs at the distribution edge. Companies that incorporate behavioral economics, information technology networks, and wholesale power markets would further enhance an integrated portfolio. Illustrative questions at the distribution edge include:

- What technology pathways are most promising for synergizing natural gas and renewable options for homeowners, commercial businesses, or communities and cities?

- What combinations of natural gas and renewable energy services address multiple, or all, energy services demands? What are the business case and impact metrics for these versus "non-coupled" energy services?

- How can larger industries optimize the use of natural gas, renewable energy, and industrial demand to increase financial performance?

- What are the synergies from distributed renewable energy with distributed natural gas, and how can firms prepare for changes in their business models?

\section{Industrial Cogeneration-Optimization for Multiple Markets}

Cogeneration illustrates the wider business opportunities that are available in industry when using renewable energy and natural gas to generate heat and electricity for use in multiple markets. Cogeneration, which can be fueled by natural gas or a renewable fuel, such as biogas, is typically sized to provide on-site thermal needs. However, many opportunities exist to optimize plant size and operational characteristics to participate in wholesale power markets and provide other energy services (see Text Box 2). Further synergies exist from, for example, using CSPgenerated heat to supplement cogenerated industrial process heat. Increased revenue can be obtained by providing power during times of peak pricing and participating in ancillary service markets. Potential electricity-based revenue streams could be further enhanced by combining cogeneration with energy services that can occur during periods of low power prices, such as desalination, which may become increasingly profitable in dry or drought-stricken areas. Demand response revenue may be material, depending on the market. By fueling a plant with biogas, a plant owner can also participate in renewable energy credit markets, contribute to corporate sustainability goals, and reduce net carbon emissions.

Text Box 2. Untapped Technical Potential

The untapped technical potential to expand CHP at existing industrial facilities:

- Sized to thermal needs: 65 gigawatts in untapped potential

- Sized to thermal needs with no cap in power output and ability to export: 130 gigawatts

(U.S. DOE and EPA 2012) 
Figure 2 illustrates the value chain for this industrial cogeneration scenario.

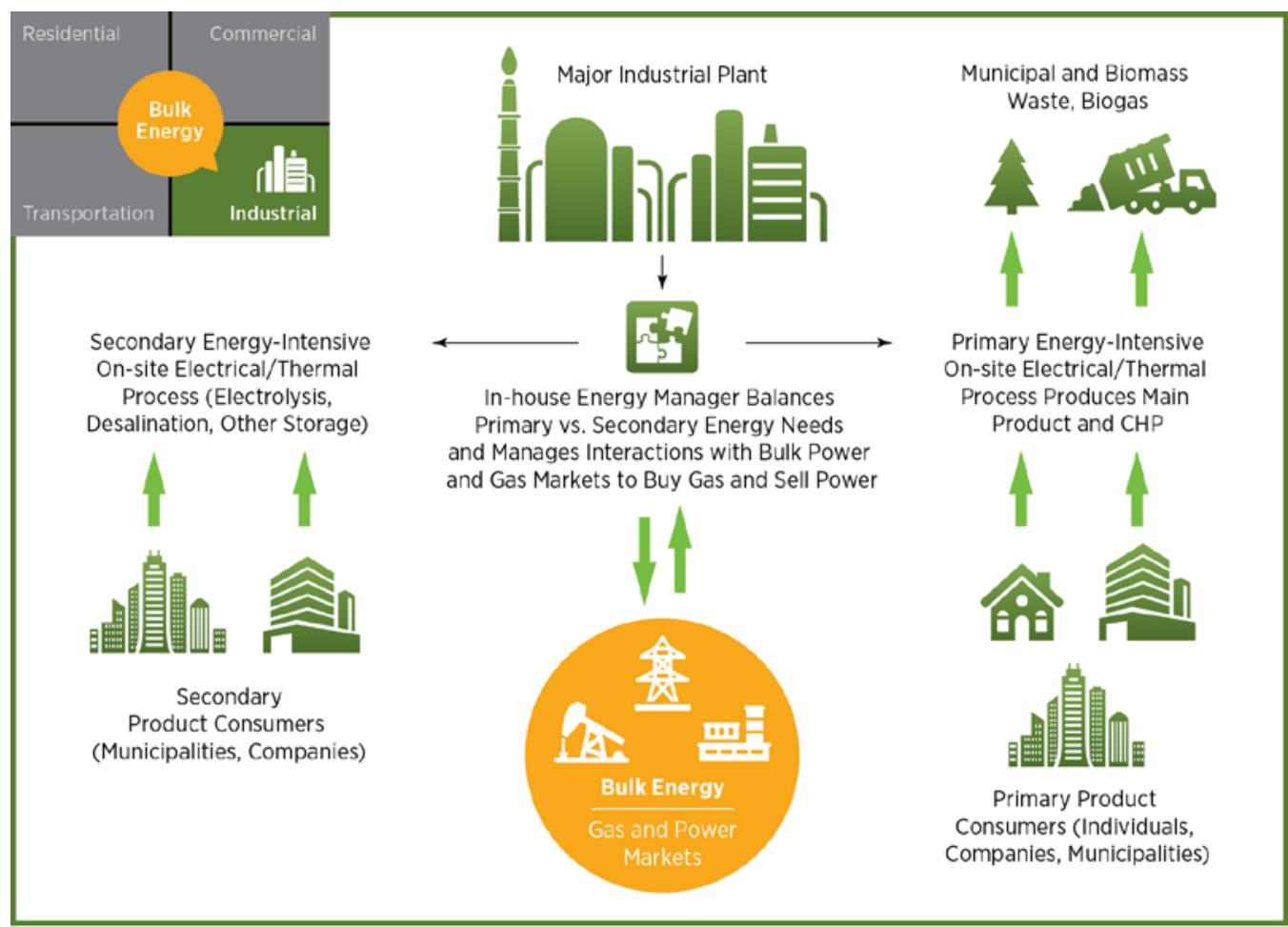

- Revenue Flow

Figure 2. Examples of revenue opportunities from synergies in the industrial sector. Green arrows represent revenue flows.

\section{Opportunities for Revenue in Synergistic Industrial Cogeneration System}

Text Box 3 summarizes the value propositions of these opportunities - for the customer (industry) and for the renewable energy and natural gas supply chains. 
Text Box 3. Value Proposition of Synergies in the Industrial Sector

Flexible fuel turbines allow for fuel diversification, added energy security, and reduced price risk. Industries can also use hybrid CHP-CSP systems to improve heat efficiencies.

Coordination of the renewable energy and natural gas industries with the utilities to address demand charges and other concerns regarding distributed generation could facilitate growth at the distribution edge. Utilities, with their lower cost of capital and longer investment time horizons, might install distributed CHP for large industrial customers and diversify revenue streams.

\section{Value proposition of synergy for:}

Customer (industrial site)

Fuel diversification offers a fuel price hedge.

Secondary market offers a hedge against lower power prices if optimizing CHP to market potential.

Power market participation helps diversify revenue streams.

Inclusion of renewable energy improves corporate sustainability goals and potentially generates renewable energy credits.

By participating in a utility self-direct energy efficiency program, the customer can avoid the cost of paying volumetric energy efficiency charges by diverting capital into a CHP system.

The customer can "island" on-site power system during a wider power outage.

The customer can leverage its existing relationship and infrastructure with the distribution company to procure natural gas.

\section{Renewable energy supply chain}

$\mathrm{CHP}$ provides a new suite of customers for biofuels.

Industrial customers offer an increased market for CSP technologies.

On-site electrolysis or storage (site owner's secondary product) could improve integration of on-site photovoltaic panels (PV) or fuel cells.

Expansion of distributed generation could help clarify tariff structures and interconnection issues, which impact plant economics.

\section{Natural gas supply chain}

Increased industrial use of CHP can expand the market for natural gas.

The potential for long-term contracts for natural gas will lead to pipeline expansion and decreased risk of congestion.

Cooperation with renewable energy developers, public utilities commission, and others to clarify tariff structures for distributed generation will facilitate expanding the market for CHP. 


\section{Residential Smart Hybrid Energy System}

Smart hybrid energy residential systems could use multiple fuel sources, smart energy infrastructure, and on-site generation optimized to provide both low-cost, reliable, clean energy for the home and energy services for the distribution grid. Such a home or aggregation of homes could use some combination of on-site solar, a natural gas or fuel cell CHP system, energy storage including plug-in electric vehicles with so-called vehicle-to-grid capabilities, natural gas vehicle refueling, or other technologies. Smart energy infrastructure would allow the home to sell electricity to the utility or participate in electric markets (including demand response), and, potentially, a natural gas demand response model. Natural gas demand response, in conjunction with other neighborhood participants, could relieve congestion on the gas pipeline system.

The residential hybrid energy system could reflect any of several ownership and revenue stream models. Three examples, illustrated in Figure 3, include:

1. The utility buys and sells electricity from the homeowner and runs a demand response program, which aggregates residential demand and sells this into the bulk power markets (e.g., capacity, ancillary services). The homeowner receives a fee or reduced bill in exchange for participation. Smart energy management equipment, PV panels, or other technologies are financed and/or owned by the utility. This example would require transforming the utility business model from one that increases revenue by increasing sales to one based on alternative performance objectives.

2. The utility buys and sells electricity from the customer. Equipment is purchased or leased by the owner. A third-party energy manager facilitates all additional energy services (e.g., demand response) and is the interface between the homeowner and the wholesale power market. This third-party business contracts with the customer to lower utility bills via energy efficiency upgrades, participatation in wholesale market opportunities, or both. The utility could supplement its revenue (not pictured in Figure 3 ) by providing information - to third-party smart energy businesses about customer demand and to homeowners about qualified service providers — by financing equipment through on-bill financing, or by doing both.

3. The third-party energy business purchases or finances smart energy equipment and operates a microgrid, and it has exclusive interaction with a group of homeowners and bulk power markets. Smoother thermal loads at the multi-home level may add to the business case for purchasing a microturbine or fuel cell. Permitting and siting processes could be streamlined if systems are installed across multiple homes or if a centralized system is used to serve multiple homes. 


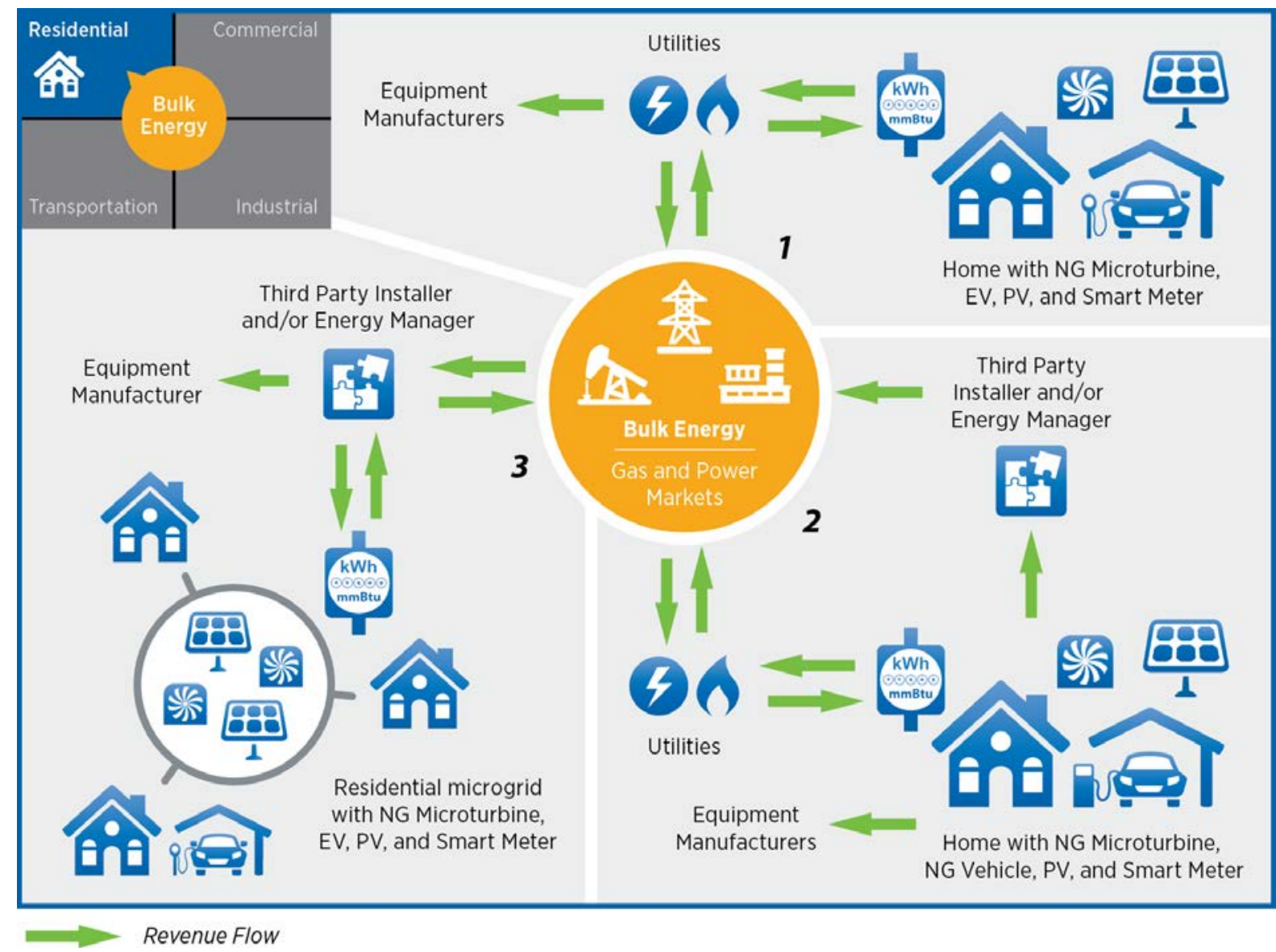

Figure 3. Examples of revenue opportunities from synergies in the residential sector. 1) Utilitymanaged and financed distributed generation and demand response programs; 2) Privately owned/leased, third-party managed residential energy system; and 3) Neighborhood microgrid managed and operated by third-party energy management company for participation in power markets. Green arrows represent revenue flows.

\section{Opportunities for Revenue from Synergies in Residential Systems}

The opportunities for revenue from synergies in the residential sector extend across many end-uses:

- Electricity - equipment installation and/or financing, energy efficiency audits and efficiency measure installations (e.g., energy service corporations), customer energy sales, power market participation, demand response program participation, on-bill financing of equipment, third-party energy management opportunities, securitization of expected electricity sales

- Heating and Cooling - home heating and cooling via natural gas CHP microturbine, equipment installation and/or financing, increased natural gas sales

- Mobility - reduced transportation fuel costs via in-home electricity, natural gas, or hydrogen refueling, in-home refueling equipment manufacturing/installation/maintenance, increased natural gas sales. 
Text Box 4 summarizes the value propositions of these opportunities-for the customer (homeowner) and for the renewable energy and natural gas supply chains.

\section{Text Box 4. Value Proposition of Synergies in the Residential Sector}

The smart energy home can participate in wholesale power markets through self-generation, demand response activities, or load-shifting using electric vehicles (EV), all of which might contribute to reduced energy bills. The home could also-through a smart interconnection of PV with CHP, fuel cells, or both-provide frequency regulation, voltage control, power, and other grid services. The smart energy system would also complement more robust distribution networks, for example, by having utilities offer contracts that optimally queue load (e.g., EV, natural gas vehicles) or through distribution network pricing (see, e.g., Brandstätt et al. 2011). Localized natural gas-to-hydrogen conversion using on-site electricity could enable economic in-home refueling of fuel cell electric vehicles.

\section{Value proposition of synergy for:}

\section{Customer (homeowner)}

Reduced energy costs; increased security and reliability

Potential to recoup EV leasing costs by participating in demand response market Insulation from major price fluctuations in electricity and gasoline

Low noise impact of fuel cell equipment

\section{Renewable energy supply chain}

Increased demand for smart home products; better opportunities for load shifting to follow renewable energy variability

Integrated energy system allows renewable energy to contribute to ancillary services, energy, and capacity markets as firm capacity

Natural gas supply chain

Increased demand in built environment

Potential for natural gas demand response where needed (e.g., Northeast)

\section{Utilities}

Diversified business growth opportunities

Variations on this opportunity can also occur in other activities at the distribution edge. For example, a campus that creates an islandable energy system could be built from smart networks among natural gas and electric vehicles, natural gas vehicles, rooftop PV, microturbines, fuel cells that use hydrogen produced from natural gas or biogas, and other technologies. A microgrid could allow the system to participate collectively in wholesale power markets. 


\section{Commercial Distributed Generation Hybrid Energy System}

Some of the synergies at the commercial level can be illustrated through an example of a big box store that generates, consumes, stores, and sells energy and energy services. In the example illustrated in Figure 4, the store could have a combination of on-site PV, flex fuel CHP, waste-toenergy combustion, and energy storage (ice or battery). For the CHP, the business can procure waste from a local municipality and, in combination with waste generated on-site, use waste to provide fuel for an on-site flex fuel CHP turbine, which can also consume natural gas. The size and types of generating equipment are optimized for the site, power market, and intended operational strategy. The PV panels could be owned by a YieldCo- the box store pays a prenegotiated monthly rate for energy, which allows significant regular cash distribution to YieldCo shareholders. A separate business installs the equipment. The box store self-finances the CHP and other non-PV equipment. A third-party energy manager runs a demand response program. The store can sell vehicle refueling (CNG) or recharging to retail customers, and it could generate additional revenue through exclusive relationships with refueling, recharging, or vehicle manufacturers (e.g., providing low-carbon power for EVs of a certain make). Off-peak power can be used to create ice for in-store cooling. As heating needs and power market conditions change, energy from the CHP system could be dynamically diverted to produce more electricity, or into a desiccating air conditioning system ${ }^{9}$ to provide cooling.

\footnotetext{
${ }^{9}$ Advanced desiccant cooling has not yet been economically demonstrated, though many companies are actively developing such technology (La et al. 2010).
} 


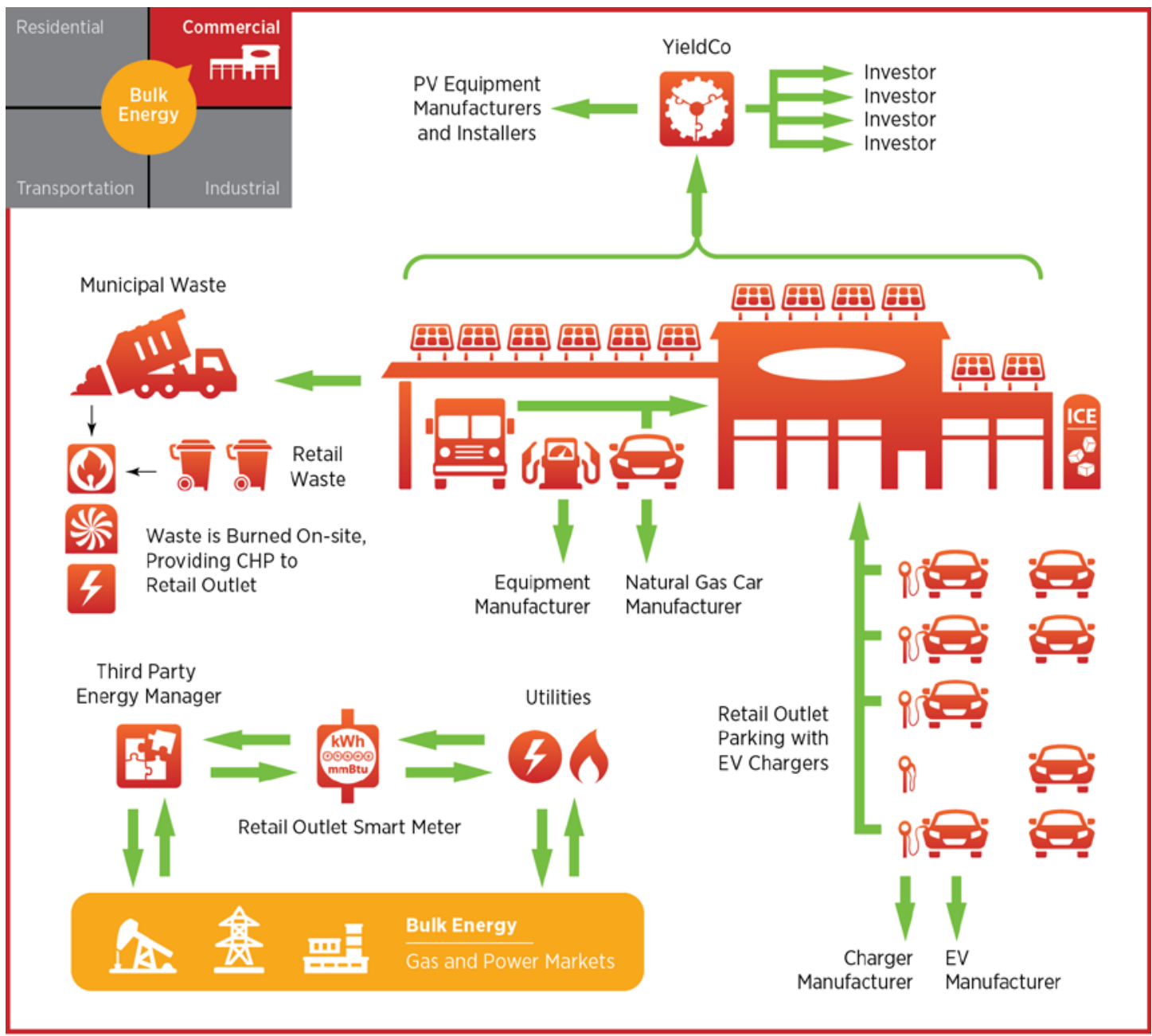

Revenue Flow

Figure 4. Examples of revenue opportunities from synergies in the commercial sector.

A commercial "big box" store provides several streams of energy services to customers and power market. A YieldCo finances and manages rooftop PV installations; several transportation fuels are available to customers; waste-to-energy combustion is used to provide supplemental electricity and heat; electrically islandable store participates in demand response program. Green arrows represent revenue flows.

\section{Opportunities for Revenue from Synergies in Commercial Hybrid Energy System}

The opportunities for revenue from synergies in a commercial hybrid energy system can benefit many businesses:

- Commercial Entity - sell excess electricity and/or demand response via utility or third party to bulk power; potentially save costs due to on-site utilization of electricity or useful heat; sell electricity or CNG to customers for vehicle fueling

- Electric Utility (e.g., a competitive affiliate serving as the owner, operator, or provider of energy services) - sell energy services (equipment, installation, operations, management) to business; provide information to third-party energy manager or commercial entity. 
- Gas Utility - sell natural gas to commercial entity (for CHP, CNG); serve as information center for smart gas network

- Third-party Smart Energy Business (owner and/or operator of the system, energy service companies (ESCO), equipment retailers) — sell/install equipment and/or energy services to commercial entity and/or utility; participate in bulk power market (including through customer demand aggregation); provide financing for equipment; securitize expected sales from production equipment; provide energy efficiency audits

- YieldCo - earn dividends for shareholders by purchasing and financing PV equipment

- Manufacturers - sell equipment (e.g., PV panels, recharging stations)

- Gas, Waste, and Biogas Supply Chain — sell fuel

Text Box 5 summarizes the value propositions of these opportunities-for the customer (commercial operation) and for the renewable energy and natural gas supply chains.

Text Box 5. Value Proposition of Synergies in the Commercial Sector

The islandable commercial hybrid energy system can provide firm capacity, ancillary services, and interruptible load into power markets, and the store can potentially provide such services in optimal coordination with other partner stores in the same electric market territory. Two sources of combustible fuel (gas and waste) for CHP offer fuel diversity and associated reduced portfolio fuel risks. If cooling load exists with time-of-day electricity pricing, the commercial entity can use lowpriced electricity at night to make ice, load shift, and provide more electricity to the grid during the day when ice is needed for cooling. Advanced desiccant cooling applications for CHP waste heat might also be explored. The power system size and operations are optimized across the sources of fuel, PV, and demand. The commercial entity is also able to offer, and provide marketing for, lowcarbon vehicle refueling and recharging. Partnerships with manufacturers of alternative fuel (EV, CNG, and fuel cell) vehicles may provide joint venture opportunities for cost sharing of refueling equipment and a co-branded marketing strategy. Such systems could also provide energy services (e.g., transportation or diesel generator fuel) during natural disasters and other instances when a large-scale grid outage prevents normal delivery of energy services. Because commercial chains, such as big box stores, have multiple locations with similar designs, economies of scale can reduce costs for energy system planning and equipment procurement, and can facilitate partnerships with manufacturers, equipment installers, financiers, and energy managers.

\section{Value proposition of synergy for:}

Customer (big box store)

Lower-priced, reliable, hedged power and energy procurement strategy

Comprehensive energy management strategy for an entity for which energy costs represent a significant share of its operating expenses (especially if cooling load)

Potential for additional revenue via power market; selling electricity or CNG to customers through charging stations

Synergistic relationships with refueling, recharging, and vehicle manufactures (e.g., offer auto manufacturer's proprietary charging equipment to provide low-carbon electricity, and receive a share of profits)

Renewable energy supply chain

Increased visibility and marketing to retail customers

Opportunities for load shifting to follow renewable energy variability, reducing the 
integration costs of renewable energy

Potential for licensing intellectual property, such as a car manufacturer's fast-charging station

Low noise impact of fuel cell equipment may make system more attractive for commercial applications

Potential to compete in electricity market: To compete with utility energy services, the renewable energy developer could partner with the natural gas supply chain

infrastructure to design and provide a complete, islandable energy system. Such a partnership would allow a renewable energy owner to earn greater revenue from markets than net metering, as gas can be competitively procured. In addition, net metering policies could change, but day-ahead markets are stable. The partnership allows diversification of revenue streams, and enables renewable energy sources to participate more dynamically in power market.

Natural gas supply chain

Generation equipment leasing model, similar to that of a PV leasing model, for natural gas microturbines, CHP, and other such technologies

Potential partnership with solar leasing company or smart energy infrastructure company to provide integrated energy system

Expanded natural gas infrastructure for car refueling

Potential for natural gas demand response system (e.g., reduce consumption when fuel needed for other local distribution requirements and in those times rely more on electric grid)

\section{Transportation-Arbitrage Opportunities through Alternative Fuel Vehicles}

Synergies at the transportation edge build on shared infrastructure of transitioning to alternative fuel vehicles and on increasing the arbitrage opportunities of end-users. Synergistic infrastructure includes:

- On-site biogas cleaning at landfills, wastewater treatment facilities, livestock operations, and other facilities that are used by fleets (e.g., municipal waste collection) or sold into pipeline infrastructure

- Infrastructure that can receive multiple forms of fuel, including renewables and conventional gas

- Liquefied natural gas (LNG)-electric-fuel cell train, fully integrated system able to maximize arbitrage opportunities in fuel procurement, sited along co-located natural gas/electric transmission corridors

- In-home refueling using existing built environment infrastructure

- Municipal or private stations for fleets and commercial stations for the public.

Figure 5 illustrates some of these revenue opportunities. 


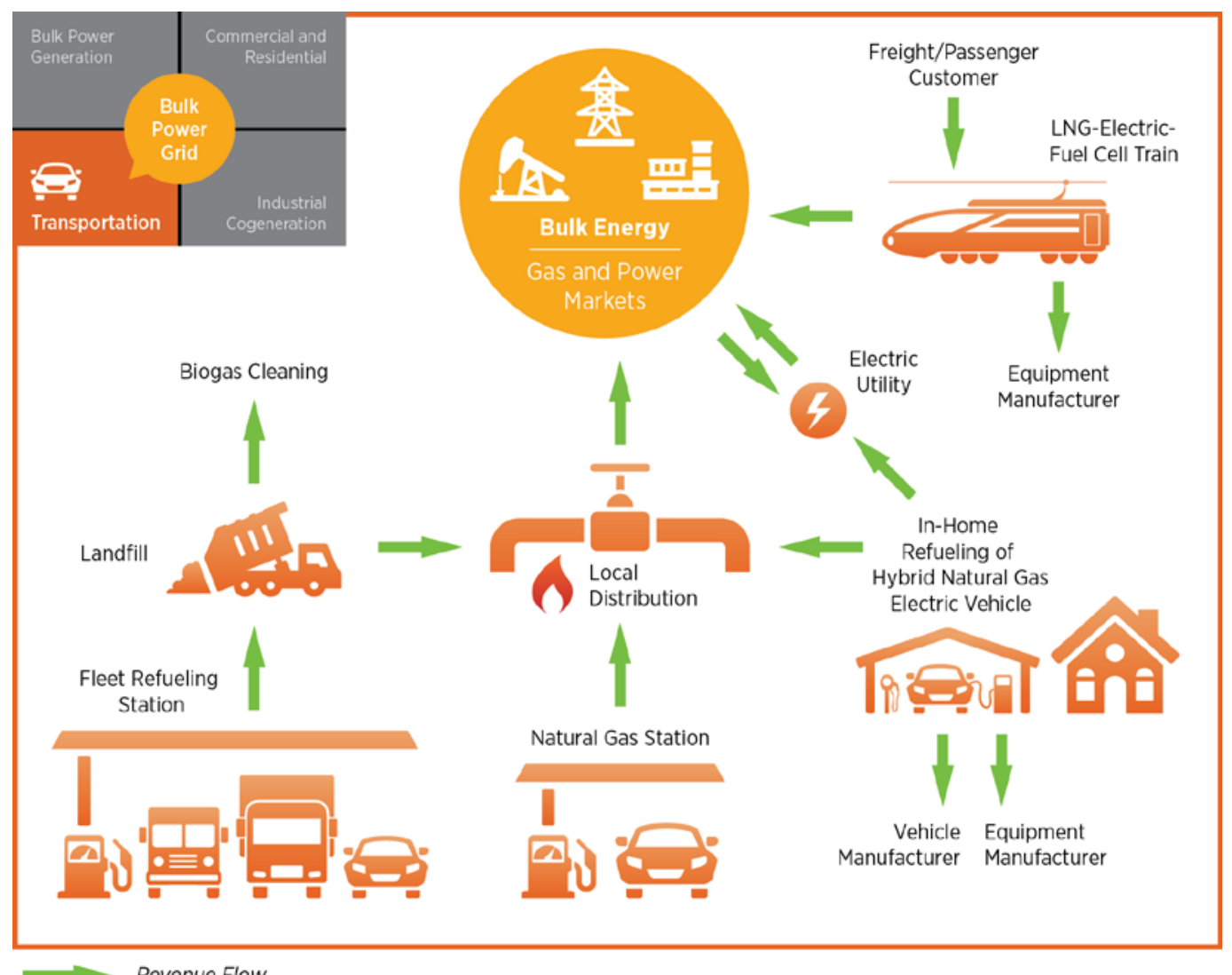

Figure 5. Examples of revenue opportunities from synergies in the transportation sector

\section{Opportunities for Revenue in Alternative Fuel Vehicle Supply Chain}

The opportunities for revenue from synergies in the alternative fuel vehicle supply chain include many types of businesses:

- Energy Retail Sales (gas utilities, refueling station owners) - refueling station revenue; combustion of biogas (or renewable natural gas (RNG)) for electricity, useful heat, and/or renewable energy certificates

- Manufacturers - biofuel production and cleaning equipment; refueling stations; in-home refueling design and equipment; natural gas vehicle and engine manufacturers, liquefied natural gas (LNG)-electric or LNG-electric-fuel cell train manufacturers

- Fuel Suppliers (e.g., natural gas developers, landfill owners, dairy, livestock operations) — fuel sales; biogas or renewable natural gas production; renewable fuel trading credit sales.

Text Box 6 summarizes the value propositions of these opportunities-for the customer (fleet owner, homeowner) and for the renewable energy and natural gas supply chains. 
Text Box 6. Value Proposition of Synergies in the Transportation Sector

Alternative fuel infrastructure for transportation enables vehicles to be fueled by one or more renewable energy or natural gas-based sources (e.g., natural gas, RNG, electricity, hydrogen). Broadening the transportation sector to include natural gas, electric, and hybrid vehicles allows a diversification of transportation fuel sources, improved energy independence, and potentially compliance with renewable fuel standards. In addition, a municipality or other landfill owner could install biogas-cleaning infrastructure and sell RNG to the public or to the utility to be blended with pipeline gas. An LNG-electric or LNG-electric-fuel cell train sited along transmission corridors could take advantage of time-of-day electricity pricing, energy storage, hedged LNG contracts, and on-board methane reformers to produce least cost motive force for the train.

\section{Value proposition of synergy for:}

Customer (fleet owner/operator)

Reduced fuel cost and diversified fuel risk

\section{Customer (homeowner)}

Convenience of home-refueling or recharging, reduced fuel cost relative to gasoline, use of existing built environment infrastructure and customer-gas utility relationships

Renewable energy supply chain (landfill gas, wastewater treatment facilities, dairy operations) Increased demand for renewably-sourced natural gas

Opportunity to use existing natural gas infrastructure Increased market for modularized biogas cleaning systems to create pipeline quality RNG

Natural gas supply chain

Considerable opportunity to enter the built environment (in-home refueling infrastructure) and commercial gas stations

Ten states allow gas utilities to rate-base natural gas stations.

Potential for fueling with low/zero carbon sources might increase willingness to invest in infrastructure, offering immediate benefits for natural gas. 


\section{Pathways to Emerging Business Opportunities}

Pathways to realize the business opportunities identified in this paper require significant effort and leadership. JISEA and the Center for the New Energy Economy hosted a Leadership Forum in September 2013 to discuss emerging business models that capture value from renewable energy and natural gas synergies, and to identify actionable next steps. The following list of actions reflects a non-comprehensive set of priorities identified by the forum participants and presents one possible strategy to move forward.

\section{Actions to Advance Synergies and Enable New Business Opportunities}

1. Create metrics for an energy system for 2050

2. Shift the basis of pricing from commodities to services

3. Incentivize the modernization of the generation fleet

4. Explore new utility business models

5. Expand the public dialogue on the synergies of natural gas and renewables

6. Utilize first-mover case studies

These six steps are presented in this section.

\section{Create metrics for an energy system for 2050}

Metrics that define a vision for an energy system in 2050 would establish economic opportunities. The metrics could define goals such as ratepayer protection and reliability, and, if they reflect public and private sector agreement, would address investor uncertainty. Metrics could also clarify currently ambiguous definitions, such as:

- What are the temporal and physical boundaries of net-zero energy structures?

- What is considered clean energy? For example, is waste heat clean or renewable?

The costs and benefits of energy projects are diverse and distributed uniquely across stakeholders. A holistic, systems approach is needed to establish new metrics and methodologies for the evaluation of energy projects. Useful metrics would:

- Assess the distribution of costs and benefits across various energy stakeholders

- Account for the relative value of various benefits to all affected entities

- Be used to assign energy project costs proportionally to the distribution of benefits.

\section{Shift the basis of pricing from commodities to services}

Pricing that more accurately reflects the value of services rather than the commodity underpinnings could better reflect costs and benefits of supply, delivery, and demand-side resources, and it could better capture the opportunities for renewable energy and natural gas synergies. For example, how can the value of clean, reliable power be better reflected in electricity pricing? In addition to internalizing environmental externalities, options include: 
- Valuing reliability and flexibility in natural gas delivery for natural gas plants

- Rewarding demand response resources not just for hours utilized but for the characteristics of their availability

\section{Incentivize the modernization of the generation fleet}

While electricity demand growth has slowed significantly in the United States over the past five years, new administrative measures - including the EPA's Mercury and Air Toxics Standard and Section 111(d) of the Clean Air Act on existing plant performance standards - could result in the need to accelerate modernization of the generation fleet. A portfolio renewal standard (rather than a renewable portfolio standard) was one idea mentioned at the Leadership Forum to ensure that opportunities for deploying advanced technologies and practices existed. Creating new business opportunities for renewable energy and natural gas energy synergies might require incentives to replace existing assets that have positive cash flows. Innovative measures that reallocate risks, such as those that do so by easing the ability to recover capital on new equipment, could provide an incentive for owners to retire plants with only a few years of cash flow remaining in favor of a new, cleaner plant with decades of anticipated revenue. A challenge is how to make this work in both vertically integrated utilities, as modeled by Colorado, and in competitive, restructured power markets.

\section{Explore new utility business models}

The electric utility industry has expressed concerns about the potential for disruptive forces on the distribution edge to threaten the traditional utility business model, which is premised on energy sales and regulated returns on investments (Kind 2013; Lehr 2013; Newcomb et al. 2013). The business opportunities identified in this paper highlight some of these disruptive forces, such as those that occur through on-site generation, demand response, and third-partyowned and operated energy systems. These opportunities reconsider traditional ownership structures of energy equipment. Yet, barriers to achieving these opportunities persist, and they include high interconnection and standby charges, which remain a source of utility revenue to maintain and operate the distribution grid. New utility business models could better position utilities to provide energy services, including through:

- Expansion of products, such as facilitating wholesale market participation and financing energy services and equipment

- New performance incentives, including decoupling energy sales from utility revenues to reward energy efficiency (Binz et al. 2012; Cavanagh 2013)

- Changing the role of the utility to that of a system integrator, with a focus on distribution system market and operations (Newcomb et al. 2013)

- Establishing the electricity grid as a public good, not a natural monopoly, to reflect the value of the grid primarily for its provision of reliability - this would in turn shift the basis of utility remuneration, such as from demand and standby charges to public funds.

\section{Expand the public dialogue on the synergies of natural gas and renewables}

The end user is the focus of an energy systems integration perspective. The desired attributes of the energy (e.g., clean, reliable, low-cost)—and the social, cultural, and political context—will 
be specific to the consumer. Public and private sector leaders will benefit from communication about different visions for user-specific energy services and from learning how roles and responsibilities (for consumers, businesses, regulators, and policymakers) may evolve. These dialogues will help shape business models and empower consumers.

\section{Develop full case studies}

This paper explores a broad range of business opportunities. A deeper investigation of a few opportunities - in the form of a case study - could help evaluate potential revenue estimates and necessary conditions (e.g., technological capabilities, institutional contexts, policies, consumer behavior, workforce skills). 


\section{Conclusions}

Traditionally, natural gas and renewables often compete for investments, and public and political support. However, potential new, value-added opportunities may exist in which the two resources provide system-level solutions that are technically and financially attractive and may garner strong and broad stakeholder support. This paper presents some exploratory, financially driven opportunities for the synergistic use of natural gas and renewables. These opportunities expand far beyond the most commonly considered pairing of gas and renewables - to minimize risk in a portfolio of investment assets. New technologies, financing mechanisms, carbon constraints, and behavioral expectations are expanding opportunities for gas and renewables in a variety of market sectors and structures. Together, gas and renewables can help provide improved energy system flexibility and resiliency; meet increasingly sophisticated customer needs; and prepare for larger, unpredictable changes in the future. The landscape - of both options for taking full advantage of the investment as well as the revenue opportunities offered via technical and financial system-level solutions - is large, allowing for unprecedented innovation and leadership. 


\section{References}

Binz, R.; Sedano, R. et al. (2012). "Practicing Risk-Aware Electricity Regulation: What Every State Regulator Needs to Know." Ceres.

Brandstätt, C.; Brunekreeft, G.; et al. (2011). "Locational Signals to Reduce Network Investments in Smart Distribution Grids: What Works and What Not?" Utilities Policy (19:4); pp. 244-254.

Cavanagh, R. (2013). "Chapter 6 - Making Cost-Effective Energy Efficiency Fit Utility Business Models: Why has It Taken So Long?" Energy Efficiency; pp. 165-178. Boston, MA:

Academic Press.

Cochran, J.; Bird, L.; et al. (2012). Integrating Variable Renewable Energy in Electric Power Markets: Best Practices from International Experience. Golden, CO: National Renewable Energy Laboratory.

Cochran, J.; Miller, M.; et al. (2013). Market Evolution: Wholesale Electricity Market Design for 21st Century Power Systems. Golden, CO: National Renewable Energy Laboratory.

Ela, E.; Kirby, B.; et al. (2012). "Effective Ancillary Services Market Designs on High Wind Power Penetration Systems." IEEE Power and Energy Society General Meeting. San Diego, CA.

EnerNex Corporation. (2010). Eastern Wind Integration and Transmission Study. Golden, CO: National Renewable Energy Laboratory.

Gampert, M.; Madlener, R. (2010). "Pan-European Management of Electricity Portfolios: Risks and Opportunities of Contract Bundling." FCN Working Paper 9/2010. Aachen, Germany: Institute for Future Energy Consumer Needs and Behavior (FCN).

GE Energy. (2010). Western Wind and Solar Integration Study. Golden, CO: National Renewable Energy Laboratory.

Hardy, R. (2009). "Applicant's Prefiled Rebuttal Testimony Witness \#17: Randall W. Hardy Exhibit NO. 16.00r." Accessed October 18, 2013: http://www.efsec.wa.gov/Whistling Ridge/Adjudication/Rebuttal Testimony/Rebuttal Testimony/16.00r_Hardy (Rebuttal Testimony).PDF.

Jenkin, T.; Diakov, V.; et al. (2013). The Use of Solar and Wind as a Physical Hedge against Price Variability within a Generation Portfolio. Golden, CO: National Renewable Energy Laboratory.

Kind, P. (2013). "Disruptive Challenges: Financial Implications and Strategic Responses to a Changing Retail Electric Business." Edison Electric Institute.

La, D.; Dai, Y.J.; et al. (2010). "Technical Development of Rotary Desiccant Dehumidification and Air Conditioning: A Review." Renewable and Sustainable Energy Reviews (14:1); pp. 130-147. 
Lacey, S. (2012). "What Do Falling Natural Gas Prices Mean for Renewables?" Accessed January 22, 2014: http://thinkprogress.org/climate/2012/01/13/403833/what-do-falling-naturalgas-prices-mean-for-renewables/.

Lee, A.; Zinaman, O.; et al. (2012). "Interactions, Complementarities and Tensions at the Nexus of Natural Gas and Renewable Energy." The Electricity Journal (25:10); pp. 38-48.

Lehr, R. (2013). "New Utility Business Models: Utility and Regulatory Models for the Modern Era." America's Power Plan. Energy Innovation Policy \& Technology LLC.

Logan, J.; Heath, G.; et al. (2012). Natural Gas and the Transformation of the U.S. Energy Sector: Electricity. Golden, CO: Joint Institute for Strategic Energy Analysis.

McAndrews, N.; Lawrence, L. (2012). "Firm and Clean: A Proposal for a Standardized Firm Electric Product Combining Natural Gas and Wind Generation."

Mendelsohn, M.; Feldman, D. (2013). Financing U.S. Renewable Energy Projects through Public Capital Vehicles: Qualitative and Quantitative Benefits. Golden, CO: National Renewable Energy Laboratory.

Mendelsohn, M.; Kreycik, C.; et al. (2012). The Impact of Financial Structure on the Cost of Solar Energy. Golden, CO: National Renewable Energy Laboratory.

Newcomb, J.; Lacy, V.; et al. (2013). "New Business Models for the Distribution Edge." Electricity Innovation Lab.

O'Loughlin, M.; Graves, F.; et al. (2012). "The Emerging Need for Greater Gas-Electric Industry Coordination." comments to the FERC NOI Docket AD12-12-000. The Brattle Group.

Olson, S. (2011). "GE's FlexEfficiency Chosen for MetCap's integrated renewables combined cycle project in Turkey." Accessed October 18, 2013: http://www.pvtech.org/news/ges flexefficiency chosen for metcaps integrated renewables combined cycle.

Porter, K.; Mudd, C.; et al. (2012). Meeting Renewable Energy Target in the West at Least Cost: The Integration Challenge. L. Schwartz, Western Governors' Association.

Schwabe, P.; Mendelsohn, M.; et al. (2012). Mobilizing Public Markets to Finance Renewable Energy Projects: Insights from Expert Stakeholders. Golden, CO: National Renewable Energy Laboratory.

Swisher, J. (2011). "The Business Case for Integrating Clean Energy Resources to Replace Coal." American Clean Skies Foundation.

Synapse. (2006). "Energy Portfolio Management: Tools \& Resources for State Public Utility Commissions." The National Association of Regulatory Utility Commissioners.

Tabors, R. D.; Englander, S.; et al. (2012). "Who's on First? The Coordination of Gas and Power Scheduling." The Electricity Journal (25:5); pp. 8-15. 
Weiss, J.; Bishop, H.; et al. (2013). Partnering Natural Gas and Renewable Energy in ERCOT. The Brattle Group.

Wiser, R.; Bachrach, D.; et al. (2004). "Comparing the Risk Profiles of Renewable and Natural Gas-Fired Electricity Contracts." Renewable and Sustainable Energy Reviews (8:4); pp. 335-363. 


\section{Appendix. Recent JISEA Publications on Natural Gas and Renewable Energy}

Lee, A.; Zinaman, O.; Logan, J. (2012). Opportunities for Synergy Between Natural Gas and Renewable Energy in the Electric Power and Transportation Sectors. NREL/TP-6A50-56324. Golden, CO: Joint Institute for Strategic Energy Analysis. Accessed January 3, 2014:

http://www.nrel.gov/docs/fy13osti/56324.pdf.

Lee, A.; Zinaman, O.; Logan, J.; Bazilian, M.; Arent, D.; Newmark, R.L. (2012). "Interactions, Complementarities and Tensions at the Nexus of Natural Gas and Renewable Energy."

Electricity Journal (25:10); pp. 38-48. Accessed January 3, 2014:

http://dx.doi.org/10.1016/j.tej.2012.10.021.

Logan, J.; Heath, G.; Macknick, J.; Paranhos, E.; Boyd, W.; Carlson, K. (2012). Executive Summary - Natural Gas and the Transformation of the U.S. Energy Sector: Electricity. NREL/BR-6A50-57702. Golden, CO: Joint Institute for Strategic Energy Analysis. Accessed January 3, 2014: http://www.nrel.gov/docs/fy13osti/57702.pdf.

Logan, J.; Heath, G.; Macknick, J.; Paranhos, E.; Boyd, W.; Carlson, K. (2012). Natural Gas and the Transformation of the U.S. Energy Sector: Electricity. NREL/TP-6A50-55538. Golden, CO: Joint Institute for Strategic Energy Analysis. Accessed January 3, 2014:

http://www.nrel.gov/docs/fy13osti/55538.pdf.

Logan, J.; Lopez, A.; Mai, T.; Davidson, C.; Bazilian, M.; Arent, D. (2013). "Natural Gas

Scenarios in the U.S. Power Sector." Energy Economics 40(November 2013); pp. 183-195.

Accessed January 3, 2014: http://dx.doi.org/10.1016/j.eneco.2013.06.008. 